\title{
On the Frontlines: Making Decisions in Chinese Civil Environmental Lawsuits
}

\author{
RACHEL E. STERN
}

This article looks at forty-two decisions in civil pollution cases in China as a window onto judges' political logic and the accompanying implications for environmental enforcement. The starting point is a typology of judicial decision making in one-party states based on two dimensions of decisions: the degree of legal formality (e.g., how closely judges adhere to the letter of the law) and individual autonomy (e.g., judges' power to make decisions in individual cases). Mapping pollution decisions onto this typology highlights shifting judicial strategy. While Chinese judges typically comply with instructions when the political pressure is dialed up, a combination of shifting incentives, uncertainty about the law, and political ambiguity can also allow de facto discretion in low-profile, run-of-the-mill cases. Everyday cases tend to cluster under the rubric of "rough justice" in which judges weigh competing political priorities and aim for a livable compromise that dents but upholds the status quo. This sample of cases also shows judges occasionally innovating at the margins by offering new legal interpretations or validating new types of claims. Although Chinese courts remain weak tools for environmental protection, limited innovation suggests that they can help nudge along local incremental social change.

\section{INTRODUCTION}

Up on the commanding heights, at the pinnacle of the state, China's top leaders agree that law should serve the Chinese Communist Party (CCP). ${ }^{1}$ Down in the trenches, at the frontlines of decision making, Chinese judges in civil environmental cases decipher this directive and attempt to diffuse local discontent. ${ }^{2}$ But why do judges make the decisions they do? This article looks

This article is based on dissertation research funded by a Fulbright-Hays Doctoral Dissertation Research Abroad Grant, a Doctoral Dissertation Improvement Grant from the National Science Foundation, and the Center for Chinese Studies at the University of California, Berkeley. This draft has benefited greatly from comments by Robert A. Kagan, Kevin J. O'Brien, and Benjamin Van Rooij. Thanks also to Jennifer Brass, Jonathan Hassid, Benjamin Liebman, Katherine Morton, Susanne Wengle, Guobin Yang, and the participants at the conference China's Changing Courts jointly organized by Columbia and NYU Law Schools in February 2009 for useful feedback on earlier drafts.

Address correspondence to Rachel E. Stern, Society of Fellows, Harvard University, 78 Mount Auburn Street, Cambridge, MA 02138. Telephone: (617) 496-0047; E-mail: restern@ fas.harvard.edu. 
at legal decisions (panjueshu) as a window onto judges' political logic and the accompanying implications for environmental enforcement.

Understanding how Chinese judges make environmental decisions offers insight into the reality of ground-level enforcement in a country well known for both serious pollution problems and weak courts. Amid increasing official rhetoric about environmental protection and public participation (gongzhong canyu), it is an open question how citizen-initiated lawsuits fit into larger efforts to limit pollution. Although the vast majority of environmental disputes never reach courts, can civil litigation serve as a backstop for the more routine combination of fines, mediation, and social suasion? Here, much depends on judicial decision making, particularly on how closely judges hew to the law and their autonomy in making their own determinations.

My primary source is forty-two decisions in pollution compensation disputes (huanjing wuran sunhai peichang jiufen) from the period 2000 to 2007 , supplemented by interviews from fourteen months of fieldwork. ${ }^{3}$ Chinese legal decisions are not necessarily public documents, and this selection, downloaded from a Beijing-based legal database, is almost certainly not a random sample. In particular, conversations with database employees lead me to suspect that this database has too many cases involving major losses, especially from rich areas of the country, and rather too few class actions. Still, even if not representative, the cases recounted below illustrate how judges think about pollution disputes and the kinds of solutions they deem appropriate. Socio-legal research on Chinese courts rarely looks carefully at court decisions, probably because they are largely seen as uninformative, pro forma recitations of the facts (Zhang 2003). Yet legal decisions are getting more interesting. In 2005, the Supreme People's Court (SPC) issued a notice telling lower level courts that written decisions should include legal reasoning (Liebman 2007). ${ }^{4}$ At least in my sample, this is starting to happen. Three pages, the average length of the decisions I examined, is long enough to hint at the court's concerns and rationale. While these opinions are not masterpieces (judges sit on an average of forty-two cases per year and primarily focus on clarity and brevity), ${ }^{5}$ they reflect, to borrow Martin Shapiro's phrase, "the popular element" in judging (1981: 56). Even courts in singleparty states are often compelled to offer public justification, however glancing, for their actions.

My starting point in analyzing these decisions is a typology based on two key elements of judicial decision making in one-party states: (1) the degree of legal formality (how closely judges adhere to the letter of the law) and (2) individual autonomy (judges' power to make decisions themselves). Thinking along these two dimensions highlights variation in judicial strategy. While Chinese judges typically comply with clear political instructions, a combination of shifting incentives, uneven application of the law, and political ambiguity produce a degree of de facto discretion, especially in low-profile, run-of-the-mill cases. Most of the cases in my sample deal with exactly this 
kind of everyday justice. While researchers tend to focus on high courts ${ }^{6}$ and landmark cases ${ }^{7}$ rather than the trudge of low-level judicial work (Kapiszewski and Taylor 2008), judges are the "assembly line workers" responsible for negotiating competing state goals and fashioning locally acceptable bargains (Zhao 2008). As others have found (Kapiszewski and Taylor 2008; Liebman 2007), rulings in mundane cases can also display legal creativity. Everyday pollution disputes show innovation at the margins as courts occasionally offer new legal interpretations or validate new types of claims. Through daily arbitration between citizen grievances and state goals, Chinese judges may slowly reshape the practice of environmental law.

\section{TWO DIMENSIONS OF JUDICIAL DECISION MAKING IN ONE-PARTY STATES}

Looking at Chinese judges as strategic actors provides entry into a broader conversation about judicial politics in illiberal states (Toharia 1975; Silverstein 2003; Popova 2006; Hilbink 2007; Moustafa 2007; Ginsburg and Moustafa 2008). In America, there is an active debate about when and whether judges strictly follow the law, vote their convictions, or strategically nudge along policy change (Baum 2006). In strong single-party states, however, less attention has been paid to judges' choices. ${ }^{8}$ Researchers often assume that, as in Pinochet's Chile, judges uphold the status quo because institutional incentives effectively bind their interests to the party's (Hilbink 2007). This conventional wisdom, although often correct, overlooks variation in the dynamics of decision making. Even when law fundamentally serves the state, the degree of extralegal interference and judicial attention to legal texts depends on regime, court, and type of case.

Two aspects of judicial decision making are particularly helpful in understanding this variation. The first dimension is judges' degree of individual autonomy. In short, who decides cases: individual judges or political elites? While a bench of three judges typically hears civil cases in Chinese courts, there is no guarantee that the judges who try the case will decide it. ${ }^{10}$ Important cases are often decided by the court adjudication committee (shenpan weiyuanhui), comprised of top court officials appointed by the local people's congress and approved by the CCP (Zhu 2007). Courts are also officially under the supervision of the political-legal committee of the local branch of the CCP, and particular cases can elicit a meeting and instructions. But the demands of scale dictate that this kind of "telephone justice" is reserved for the most high-profile, politically sensitive cases. Chinese courts handle hundreds of thousands of civil cases each year (4.7 million in 2004), and only a small percentage is important enough to warrant external attention (Zhu 2007: 205). Observers suggest that criminal cases are most likely to trigger intervention from the political-legal committee, especially when government bureaus disagree (Yu 2009). Judges, at least in most everyday civil cases, are quietly left to the day-to-day work of hearing cases and making decisions. 
The second dimension is adherence to the law, or what law scholars call legal formality. At one extreme, judges apply the letter of the law without consideration for consequences or extenuating circumstances. At the other extreme, laws and regulations give way to wide-ranging judicial discretion. Lower court judges are particularly likely to engage in this kind of informal problem solving to maintain local harmony (Coates 1968; Nader 1990). Keeping both sides happy, even if it means bending the law, makes intuitive sense to local judges concerned with avoiding further conflict and maintaining judicial prestige. As one Australian chief magistrate explained, "it's 80 percent dealing with people [and] 20 percent law" (Roach Anleu and Mack 2007: 191).

Conceptually, both dimensions are a continuum with room for intermediate positions between the two poles. In particular, political elites are capable of influencing individual cases through signaling that stops far short of an official meeting or phone call. When law is officially subordinated to the state, party values permeate courts and judges naturally think like apparatchiks. Directions are usually unnecessary when the vast majority of judges are CCP members ${ }^{11}$ and all judges are well-steeped in party priorities. This is true in many large organizations; even absent specific instructions, general announcements, rumors, and common sense give workers a good idea of what bosses want. In investigating the 1986 Challenger explosion, for example, U.S. physicist Richard Feynman concluded that President Ronald Regan had not rushed the space shuttle launch to coincide with his annual State of the Union address. Rather, as Feynman writes, "the people in a big system like NASA know what has to be done-without being told" (1988: 217). ${ }^{12}$

Plotting these two dimensions against each other yields a useful typology of judicial decision making in one-party states (see Figure 1).

Legalism, in the upper-left corner, is what Nonet and Selznick call "autonomous law" (1971). This is a "model of rules" that values procedure, regularity, and fairness where judges are constrained by statutes and precedents (ibid.: 53). In illiberal states, the combination of scrupulous attention to the law and judicial autonomy produces a system like apartheid South Africa (Chaskalson 2003) or Pinochet's Chile (Hilbink 2007). Taboos against political behavior, as Hilbink observed in Chile (ibid.), or a culture of legal positivism compel adherence to the law, moderated by a small amount of discretion that is both legally permissible and politically tolerated. Laws leave judges some room for personal judgment, perhaps in their interpretation of the law or the penalties associated with breaking it. Apartheid-era judges, for example, sentenced Nelson Mandela to life in prison rather than death, a flash of clemency that changed the course of South African history (Chaskalson 2003).

In the upper-right corner, which I call legalized subservience, political goals are written into highly specific laws that leave judges little room to maneuver. In East Germany, for example, "innumerable instructions, analyses, inspections and consultations" helped judges "find the politically correct 
Individual Automony: Degree of Decision-Making Power

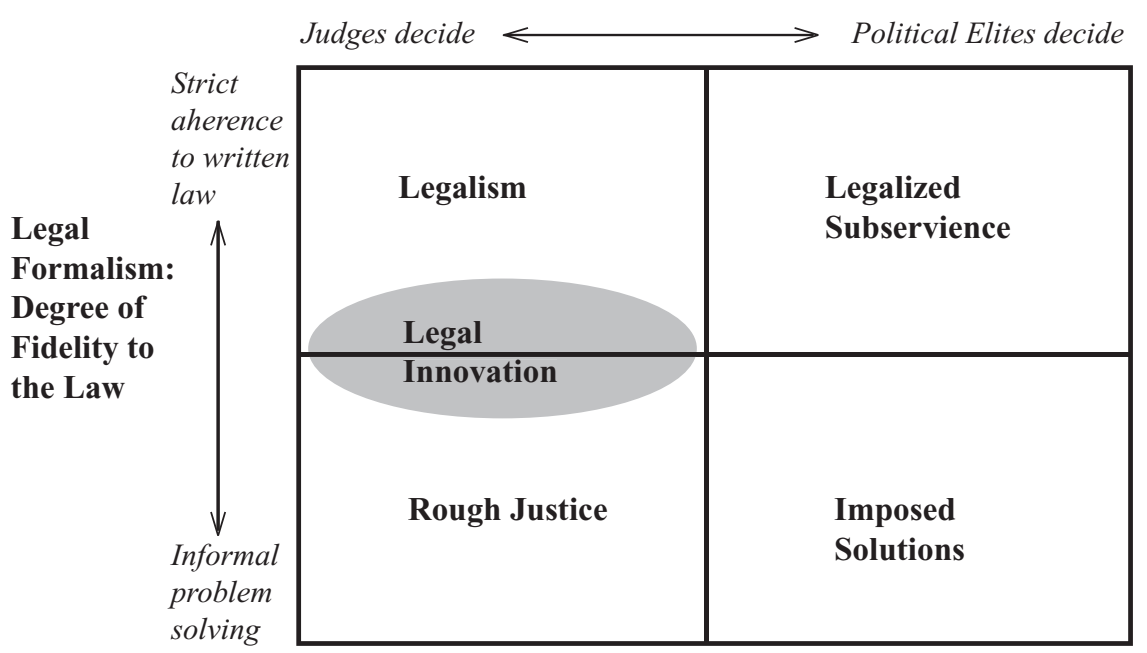

Figure 1. Judicial Decision Making in One-Party States. ${ }^{13}$

solutions to social ills whose diagnosis and remedy usually had already been prescribed by the Party" (Markovits 1996: 2293). This kind of legal specificity is an especially common way to deal with political dissent, through Nuremberg-like laws that identify, target, and punish enemies of the regime. Even the most illiberal regimes are image-conscious, and legalized subservience obscures repression with flawlessly legal language. Sometimes, oneparty states also shunt highly political cases into subservient tribunals while allowing judicial autonomy in ordinary cases. Franco's Spain, as Toharia (1975) points out, preserved the appearance (if not the reality) of independent justice through separate military courts targeted at subversion.

When judges diverge from the law, in the bottom half of the typology, decisions are likely to either protect the influential or feature a compromise. In the lower-left box, termed rough justice, relatively independent judges forge informal solutions. Sometimes, outright corruption or social pressure (guanxi) induces judges to take a side. Absent a personal interest in the outcome, however, Shapiro's logic of the triad mediates toward compromise (1981). The need to convince losers that both the outcome and the process were fair points many judges toward the Zapotec Indian conclusion that "a bad compromise is better than a good fight" (quoted in Nader 1990: 1).

Still, whenever top cadres make their interests known, the reality of a party-subordinate legal system pushes most judges toward the safety of the lower-right box and an imposed solution. As one judge recalled an instance of strategic retreat, "the president addressed me at the very beginning of this lawsuit, saying 'the Environmental Protection Bureau acted groundlessly; you have to pay close attention in handling this case" " (Zhang 2008: 146). 
Imposed solutions means that everyone from old school chums to stateowned enterprises can negotiate special legal treatment, provided, of course, leaders prove willing to extend themselves.

The zone of legal innovation, in which judges push and expand the boundaries of the law, lies halfway between rough justice and legalism and overlaps both. In well-established, independent legal systems, legal creativity often corresponds to what Nonet and Selznick (1971) call responsive law. Judges base decisions not just on a legalistic reading of rules but also on substantive concerns about justice. Law is flexible, political, and potentially unstable because judicial interpretation offers a way to change the very substance of the law itself (ibid.). Yet legal creativity is deeper and hardier than responsive law. A close reading of Chinese civil environmental cases shows a dollop of innovation where we would least expect to see it: in a one-party state inculcated in a civil law tradition of judges as "expert clerk[s]" (Merryman 1985: 36). Even in relatively inhospitable environments, there can be room for new inferences and interpretations.

Beyond my particular case, these four ideal types of judicial logic highlight the shifting pressures on judges in illiberal states. Legal systems may not fit neatly into one box because justice varies not only between countries, but also within them. Particularly in large decentralized court systems, judges' individual autonomy and the degree of formalism differ locally. Just as environmental enforcement depends on local circumstances (Van Rooij and Lo's article in this issue), so too does judicial logic and outcomes. In addition, judges' strategy may shift with the type of case. Certainly, parallel courts for political sensitive cases - what Moustafa and Ginsburg call a "fragmented court system" (2008: 17) - show a different approach to judicial decisions from that of their mainstream counterparts.

More immediately, these two dimensions offer a precise way to discuss the dynamics of decision making in civil environmental cases. As discussed below, my sample of forty-two cases features low legal formality and fluctuating autonomy from external pressure. Most of the cases fall under the rubric of rough justice, although imposed solutions are also possible when political elites make a clear preference known.

\section{FLUCTUATING AUTONOMY}

Judicial choice is hard to see (and even harder to study) because it is frequently concealed. Judges disguise discretion in authoritative decisions "written to look like a standard drill in legal reasoning" (Amsterdam and Bruner 2000: 202). The goal is not to debate the law, but to dispel doubt and dissuade appeal. Yet, contrary to the conventional image of Chinese judges as bureaucratic automatons, pollution lawsuits suggest that judges enjoy a fluctuating degree of autonomy. In addition to practical issues (e.g., the fact that political elites cannot possibly weigh in on every decision), discretion 
stems from splotchy application of the law, legal silences, and the ambiguity of underlying political goals. Uncertainty about both legal principles and state priorities, in short, lends judges the political and legal cover to plausibly defend the decision they see fit.

Legally, civil environmental cases hinge on two points. First, the Environmental Protection Law, a 1991 Environmental Protection Bureau circular, and State Council regulations agree that polluters must pay pollution victims even if discharge meets government standards (Wang 2005). Second, the 2008 Water Pollution Law, the 2004 Solid Waste law, and a 2002 explanation (jieshi) by the Supreme People's Court (SPC) shift the burden of proof so that defendants are responsible for proving that pollution did not cause losses. This latter point is particularly important for pollution victims looking for compensation. Environmental cases turn on causation, and it is notoriously difficult to prove (or deny) a connection between pollution and harm.

In practice, my set of decisions - almost certainly publicly released because court leaders thought the law was correctly applied and that the cases merit reference ${ }^{14}$ - show widespread confusion on both counts. Several courts imposed a litmus test whereby the illegality of emissions was a prerequisite for court-mandated compensation, ${ }^{15}$ and many more did not reverse the burden of proof..$^{16}$ Judges, perhaps unaccustomed to pollution cases and unfamiliar with environmental laws, tended to default to the General Principles of the Civil Law. The General Principles, which should be trumped by more specific environmental regulations, limit liability to polluters who do not comply with environmental standards and who operate according to the logic of "whoever claims it, proves it." This gap between national laws and local implementation is not surprising, but the key point is that irregular application of the law gives judges a degree of freedom to diverge from it. Absent a uniform understanding of basic legal principles, ignorance becomes a credible (and quasi-acceptable) defense for questioned decisions.

The deeper source of discretion, however, is the silence of the law surrounding evidence. Evidence is scarce, both because state-of-the-art environmental testing is rare and because collecting the data that does exist is hard. Judges are responsible for investigating the unclear aspects of a case, but many lack the time or desire to do a good job (Personal Communication (PC) 2007-55; PC 2007-103). One significant problem is that soliciting evidence frequently requires wheedling reports out of bureaucrats who have little incentive to cooperate. One conscientious Tianjin judge made three trips to the Environmental Protection Bureau to obtain pollution data, succeeding only after he went drinking with local officials (PC 2007-74). Other judges see gathering evidence as a liability because simple facts and short decisions are easier to defend on appeal (Upham 2005).

In addition, judges lack guidelines about how to use the evidence they have. In one typical case, Ye Hanjia and his family sued a Guangdong chemical company for RMB950,000 (US\$139,700) for medical expenses, after he lost work time and suffered emotional distress from poisoning caused 
by a chemical spill. ${ }^{17}$ Ye and his family presented medical records (from both directly after the accident and about nine months later) as well as photos of the scene as evidence. The defendant supplemented this with (1) a copy of its operation permit, (2) a public health bureau report stating there were no illegal emissions three months after the accident, (3) a pollution control center statement that Ye's family no longer exhibited symptoms of poisoning several months postaccident, and (4) a copy of the initial compensation agreement with Ye. There were no epidemiology reports, competing opinions from groundwater experts, or even pollution data from the day of the accident. The Dongwan judges, in other words, lacked information about the two most important facts of the case: the severity of the spill and the cause of the Ye family's original illness. Much like nineteenth-century magistrates, they simply had to decide whose evidence to believe and what was fair.

Finally, the diversity of CCP political goals offers judges flexibility in resolving cases. Sometimes, of course, powerful polluters - maybe major taxpayers or historic state-owned enterprises-leverage political connections to fix decisions. When dealing with the less powerful, however, the political logic is complicated. Economic growth is always a top CCP priority, but there is increasing recognition that environmental protection matters too. ${ }^{18}$ Above all, leaders are concerned about unrest inspired by pollution. In 2006, pollution-related mass incidents (the officially sanctioned term for protest) rose 29 percent (Pan 2006) with 60,000 incidents that year (Plumer 2008). For judges, pollution disputes mean navigating varied and conflicting state objectives, including economic growth, social stability, and the protection of vulnerable groups. As anthropologist Anna Lora-Wainwright observed in a Sichuan village, "the clashing targets put forward by the central state itself pose a challenge to local cadres' ability to implement central directives" (2009: 62). The government's interest is genuinely complex, sometimes allowing judges room for their own interpretation.

Part of the story here is a divergence between national and local political goals. Since 2000, a raft of new and revised national environmental laws have strengthened standards and increased penalties for violations (Van Rooij 2006a). These environmental laws, however, are often subverted by local officials and communities concerned with making money or maybe with just scraping by. Local evasion of central environmental directives merits its own Chinese term, local protectionism (difang baohu), frequently evoked as an explanation for China's environmental problems. National policies, at least according to some local officials, ignore the imperative to maintain a tax base and keep up employment. As one Sichuan township vice mayor put it, "the upper level of government invites you to dinner, but the local government pays the bill” (Tilt 2007: 927).

On the ground, it is not always easy for judges to read the political winds. The local government's "tolerance interval," to borrow Epstein, Knight, and Shvetsova's term, is hazy, especially when cases touch on multiple goals (2001). As a result, judges afraid of getting it wrong routinely solicit ideas on 
how to handle tough cases from other judges in the same division (PC 2007-55), senior judges (PC 2006-6), party committees (Zhu 2007: 183), or higher-level courts (Liu 2006: 93-94). Even SPC judges in Beijing receive occasional requests for advice from judges nervous about environmental cases (PC 2007-84; PC 2007-85). Often, the advice is as political as it is legal. Top court officials are political appointees (vetted by the party committee of the local government and approved by the local people's congress) who are trusted to transmit party priorities. ${ }^{19}$ As some environmental decisions openly note, ${ }^{20}$ the most important cases are not decided by the judges present at the hearing but by an adjudication committee of senior judges and court officials. ${ }^{21}$

From a systemic perspective, however, giving advice is a time-consuming burden for higher-level courts already struggling to manage their own caseloads. In the mid-2000s, SPC documents and public statements began signaling that judges should ask for advice only in influential cases or in cases where there is a dispute about the law (Zhu 2007). Requiring decisions to be made locally, of course, lends local judges de facto power to weigh conflicting government priorities. In response, judges sometimes choose to prioritize moral imperatives over economic ones. Judges talk about feeling responsible for the down-and-out masses (laobaixing), occasionally showing visible sympathy for the vulnerable (PC 2007-74; PC 2007-57; see also Gu 2008). At times, the new national emphasis on environmental protection also surfaces in lower court decisions. As one Guangdong court wrote, "environmental protection is a basic national policy (jiben guoce) because behavior that infringes on environmental rights not only endangers our health and living environment, it also causes incalculable harm to the environment of future generations." 22

In a far-flung, deeply political court system, this limited degree of judicial autonomy varies. Disputes between citizens, such as noise complaints, rarely trigger the same kind of external pressure as high-profile, politicized cases. While it is difficult to discern the tipping point at which lawsuits become politically sensitive, judges clearly spend most of their time handling commonplace cases. Here, as He (2009) notes in his work on divorce disputes, judicial discretion depends on the court (see also Liebman 2007). Just as resources and legal knowledge accumulate in some courts more than others (He 2007), some judges have more autonomy than others. In research on three Sichuan courts, for example, Lan (2008) found a wide range of judicial decision-making power in criminal cases. Depending on the court, judges (rather than higher-court officials or the court adjudication committee) made decisions 89 percent, 68 percent, or 0 percent of the time.

In large part, the degree of discretion depends on the local specifics of judicial evaluation. Courts issue yearly indicators of decision-making quality (shenpan zhiliang pinggu zhibiao), which include the number of appeals, complaints, and retrials (Ai 2008; He 2009). These numbers are used in judges' annual evaluations. Doing a good job leads to raises, better housing, and 
access to court cars. Doing a bad job might mean fines for "wrong decisions" (cuo an) or, in extreme cases, demotion or transfer to a different court or government bureau. Particular rewards and punishments, however, vary (Yu 2009). In some places, for example, the criteria for a "wrong case" includes incorrect legal reasoning or mere reversal, while, in other places, it is limited to instances of corruption and decisions with no basis in law (ibid.). ${ }^{23}$ Wrong decisions can, as in Gansu, result in a two- to four-point loss on evaluations linked to annual bonuses (ibid.), or, as in Shanghai, warrant only a minor RMB100 fine (PC 2007-55). Variation in local incentives, as Yu (2009) points out, gives some judges more motivation than others to puzzle out political tolerance intervals and position themselves accordingly.

In short, judges in environmental cases can be powerless or powerful. When it exists, judicial discretion influences the tenor of proceedings as well as the outcome. In a Hebei environmental hearing I attended in January 2008, judges allowed a representative from the Beijing-based Center for Legal Assistance to Pollution Victims (CLAPV) to both sit with the plaintiff's counsel and to give a speech, even though the nongovernmental organization (NGO) had no official role in the courtroom. The representative used the speech to frame the dispute ("this is a typical water pollution case") and lend prestige to the plaintiff's cause. The head of CLAPV, the representative name-dropped, was busy helping the National People's Congress revise the Water Pollution Law, but his organization was "here today to help the plaintiff use the law to protect his rights." The court president sat in the front row during the hearing, and the unusual presence of external observers (including me) likely encouraged him and other court officials to consider the plaintiff's case carefully.

Most of the time, however, uncertainty about actors' tolerance guides judges toward conservative, by-the-book decision making. Risk-adverse decisions are common sense when, as in one Zhejiang lower court, annual bonuses equivalent to four months of salary require the court president's signature (PC 2006-6). And in the instances when elites signal the limitations of tolerance, possibly through a carefully worded expression of concern, an ad hoc retreat to an imposed solution is the norm. In the end, as Ran Hirschl writes about judges elsewhere, courts "hand down decisions that favor the powerless primarily when doing so is consistent with elite values and interests" (2008: 109).

\section{ROUGH JUSTICE}

Writ large, legal systems provide "an echo chamber for conversations about credit and blame" (Tilly 2008: 35). But in individual struggles, like that of the Henan farmer blaming a paper factory for his dead fish or that of the Beijing insomniac living next to a noisy bus depot, what does this conversation look like? Here, legal decisions offer one way of inferring how Chinese judges 
think about responsibility and fairness. ${ }^{24}$ In terms of the typology discussed above, this set of cases cluster around "rough justice." Decisions aim to defuse grievances by balancing a near-overwhelming state imperative for economic growth with concerns about vulnerable groups, pollution, and social stability.

Most immediately, judges hope to leave both parties satisfied. The "biggest headache," one Chinese judge explained, is when decisions trigger complaints to supervisors (PC 2007-55; see also He 2009). Judges work hard to ensure influential parties retain a positive impression of the court. When Beijing lawyers showed up in small-town Zhejiang to handle a pro bono environmental case, for example, the court sent a car to pick them up and judges took them out to dinner after the hearing (PC 2007-51; PC 2007-97). Balancing interests and keeping both sides happy frequently translates into pragmatism. At least in environmental cases, Chinese judges often follow U.S. Judge Patricia Wald's advice to employ "pragmatism that decides cases on the merits ... [and] takes all the circumstances, including precedent, real-world significance and institutional relationships ... into consideration, tempered on occasion by compassion" (1992: 181). Few judges, in China or elsewhere, have a "visionary or crusading bent," and environmental decisions tend to divide responsibility and split the difference in a way that dents but upholds the status quo (Posner 1993: 3).

Balancing and pragmatism are most visible in the way that judges handle compensation. Depending on the number of plaintiffs and the extent of the losses, pollution disputes cases can involve significant damages. The average case in my sample involves a claim of RMB1.02 million (US\$150,000), although there are some big-money outliers like the 2000 case in Shanxi in which a village sued for RMB18 million in damages (US\$2.6 million). ${ }^{25}$ While these numbers are not representative, each case highlights the difficulty of translating legal principles into real cash payouts.

This is often the point at which judges diverge from the law. Citing "discretion" (zhuoqing), judges find a variety of reasons to lower compensation. In a case in Fujian, for example, the court slashed requested compensation by 30 percent on the grounds that the defendant should not bear full responsibility when noise pollution is the inevitable result of flaws (quexian) in national development policies. ${ }^{26}$ Courts assess damages, as one decision explained, "from the perspective of justice and reasonableness" (cong gongping heli de jiaodu). ${ }^{27}$ As in a 2003 dispute in Anhui over air pollution from a neighborhood bathhouse, a reasonable standard often encompasses nonlegal factors, like the proprietor's ability to pay. ${ }^{28}$ Even plaintiffs sometimes take their opponent's financial situation into account. One group of Hebei villagers dropped RMB45,000 (US\$6,617) of peach tree damages in light of "the defendant's financial difficulties." ${ }^{29}$

In addition to extralegal rationalization, judges also come up with legal reasons to adjust compensation. In the absence of official guidelines detailing how to allocate blame, one common strategy is to divide legal responsibility. 
Fish farmer Wang Shouxiang's failure to mitigate the effects of pollution, a Zhejiang court found, entitled him to only 56 percent of his requested compensation. ${ }^{30} \mathrm{Or}$, as a Shandong panel argued, plaintiffs should have sought out government bureaus to help combat pollution. ${ }^{31}$ Lack of due diligence, at least in this interpretation of the law, has financial consequences. Another strategy, as in cases in Shandong and Anhui, is to dismiss compensation requests unaccompanied by a stamped, official receipt. ${ }^{32}$

Regardless of judges' rationale, this group of environmental cases shows how frequently judges compromise by granting part, but not all, of a plaintiffs' requested compensation. Across all cases, plaintiffs were awarded an average of 29 percent of their claimed losses. ${ }^{33}$ Judges were slightly less favorably inclined toward mass cases (defined as those with more than five plaintiffs), granting plaintiffs 24 percent of claimed compensation. In nonmass cases, plaintiffs managed to get orders awarding an average of 42 percent of requested damages. These numbers fit lawyers' perception that judges mandate compensation based not primarily on the law, but on their (not always accurate) impression of what polluters can afford (PC 2007-23; PC 2007-27).

Judges' tendency to split the difference, to a large extent, shows a pragmatic impulse to locate a compromise acceptable to both sides. In addition, judges sometimes reduce compensation because they believe pollution victims are exaggerating losses. Judges, according to one Beijing lawyer, frequently ask questions like "how can farmers make so much money?" (PC 2009-5). Here, judicial wariness reflects the real presence of fraud. One Guangdong court caught a farmer cheating when back-of-the-envelope calculations revealed that the number of dead fish he claimed could not be conceivably packed into a pond the size of his fish farm. ${ }^{34}$ Or in Yunnan, farmers planted trees difficult to cultivate under the best environmental conditions and then demanded pollution-related compensation when the trees failed to grow (Van Rooij 2006b: 153).

Faced with uncertainty about the law and overlapping political priorities, judges in environmental cases often take refuge in common sense. In a rare moment of transparency, a Guangdong court wrote out a checklist for environmental cases in a 2005 decision: (1) whether there is pollution, (2) whether there is harm, and (3) whether there is causation between pollution and harm. ${ }^{35}$ When these determinations prove difficult, as they frequently do, judges and lawyers alike find themselves thinking about the average citizen. A Shanghai court, for example, sided with a plaintiff in a 2004 light pollution case because the brightness "exceeded what a normal person can stand." ${ }^{36}$ Or, in a 2001 case in Hebei, the defense argued that noise and vibrations from a railroad could not possibly cause cracks in neighboring house. According to the defense, the plaintiff's claim was not even worth discussing because "there's no need to prove common sense." 37

Common sense, as invoked in these cases, is an extension of local knowledge. Judges are enmeshed in local communities and, as a result, frequently 
come to the case with a preexisting understanding of the situation..$^{38}$ Industrial pollution, at least for one Henan court, does not need proof because "everyone knows about [it]." ${ }^{39}$ In another case in Inner Mongolia, industrial discharge into the Yellow River reduced Baotou City's water supply to a single back-up reservoir (Zhuang 2006). Baotou judges, like all city residents, were angry about the water crisis and favorably disposed to a large settlement (PC 2007-99). At other times, of course, local ties sway judges toward the polluters' perspective. Social suasion from friends and relatives, in addition to pressure from officials, lawyers, plaintiffs, and defendants, is part of most judges' job (Peerenboom 2002). Isolated objectivity is rarely worth the cost of loneliness and even local ridicule (He 1999).

Judges' deep local roots also help them identify and handle cases with a high probability of trouble (keneng naoshi de anzi). Pollution lawsuits can shade into protest, especially when the financially desperate are certain they have been wronged. This on-the-streets anger occasionally surfaces in written decisions, an implicit judicial acknowledgment of the permeable boundary between law and justice by other means. Judges noted that Mr. Ye, the Guangdong man whose family was diagnosed with pesticide poisoning, originally received compensation only after he was arrested for digging up the road leading to the chemical factory. ${ }^{40}$ Or, in a 2005 case in Yunnan, a village halted factory production for almost a year by blocking delivery of raw materials. ${ }^{41}$ Volatile cases, one judge explained, "are urgent and it's important to get a decision out quickly" (Zhao 2008). When emotions are running high or when there are a lot of plaintiffs involved, courts frequently refuse to hear cases altogether (PC 2007-38). Local connections help risk-averse judges manage the critical extralegal work of avoiding intractable cases and fashioning acceptable bargains.

\section{INNOVATION AT THE MARGINS}

One advantage of reading forty-two legal decisions is that the cases collectively offer a sense of the limits of the law, or the legal frontier. As environmental lawyers know, Chinese courts are much more comfortable with some kinds of grievances than others. Above all, judges treat pollution cases as private economic disputes, solvable via negotiated monetary settlement. Nonmonetary claims, such as a request for an apology, ${ }^{42}$ moving a factory ${ }^{43}$ or recognizing herdsmen's land rights, ${ }^{44}$ are usually ignored. Lawyers were still struggling to draw a legal connection between illness and pollution during my fieldwork in 2006-07, a tough sell because courts fear a landslide of similar cases (PC 2007-103). As one prominent environmental lawyer told the New York Times in 2007, "no previous [mass] lawsuit has proved the link between pollution and cancer, but I am optimistic that we can be successful" (Mackey 2007).

Yet despite strong incentives to avoid controversy, Chinese judges occasionally innovate. By and large, environmental decisions bypass the sweeping 
rhetoric of landmark decisions in favor of understated innovation at the margins. Decisions quietly validate new types of cases, like China's first light pollution case in Shanghai in $2004,{ }^{45}$ and new types of claims. Compensating cancer villages may fall beyond the current legal frontier, but some court decisions recognize that pollution affects health ${ }^{46}$ and award compensation for emotional distress caused by noise..$^{47}$ In egregious cases, like the 2004 case that left the city of Baotou without clean drinking water for five days, courts can also shift litigation cost onto defendants and order payouts large enough to compel national media attention. ${ }^{48}$

These moments of divergence from the mainstream are significant because they show judges pushing the boundaries of the law. By echoing environmental rhetoric, as when a Beijing court wrote that "the environment is a basic condition of human existence and development," courts also validate it. ${ }^{49}$ As one judge wrote, "rights that are not written in the text of the law, but are hidden between the lines, can be discovered" (quoted in Kellogg 2007: 180). In a Shanxi village, for example, judges found that pollution infringed on "residents' right to health, leisure and property." ${ }^{50}$ Other judges connected pollution disputes to the "right to use your house normally" 51 and "the right to live peacefully and right to health." ${ }^{2} 2$ The appearance of rights talk in lower-court decisions shows how deeply it has penetrated the Chinese state. ${ }^{53}$ Certain circumscribed rights, at least, are edging toward entitlements by dint of official repetition.

Taken individually, each foray beyond the legal frontier-the appearance of rights language in a decision or support for a new claim - is not of great significance, especially because the Chinese legal system has neither judicial review nor binding precedent. Taken together, they indicate systemic tolerance for modest innovation, especially in cases that do not touch powerful local interests (Liebman 2007). Room for innovation has also expanded along with the number of smaller polluters. An increase in the number of enterprises from 165,080 in 1998 to 323,793 in 2007 means that environmental lawsuits can increasingly target less-protected polluters rather than major state-owned enterprises (Van Rooij and Lo in this issue).

Isolated instances of innovation may also ripple through other courts, slowly shifting the mainstream interpretation of environmental law. Liebman and $\mathrm{Wu}(2007)$ document a trend toward soft precedent in which lower courts look at other decisions for guidance in handling difficult cases (see also PC 2007-55; PC 2007-74; Kellogg 2007).$^{54}$ In my sample, a 2002 Guangxi highcourt decision discusses the legal implications of a similar case, ${ }^{55}$ while the Zhejiang high court looks even further afield toward "principles commonly used by every country in the world in handling environmental pollution rights infringement cases." ${ }^{56}$ The groundbreaking 2004 Shanghai light pollution case was also written up in the Supreme People's Court Gazette (Zui Gao Renmin Fayuan Gongbao), a clear indication that higher-ups thought the case merited widespread attention and reference. Sometimes, lawyers even observe movement in the legal frontier as a set of local judges becomes 
accustomed to new types of claims. Zhou Litai, one of China's best-known labor lawyers, recalls a four-year progression from losing almost every case to winning 40 to 50 percent of the time (Zhou 2005).

Incursions beyond the legal frontier occur, in large part, because judges have incentives to innovate. Local government is a common testing ground for economic and legal reforms in post-Mao China, and the most successful innovations are adopted nationally. ${ }^{57}$ This is career-making stuff, and there is no shortage of ambitious judges angling for attention from higher-ups. Officials from the innovative administrative division of the Pingdingshan Intermediate Court, for example, have been invited to national-level SPC conferences-public recognition that is both immediately gratifying and holds the promise of possible future promotions (Yu 2009). Some judges also subscribe to the "no action, no authority" (yiwei zhengwei) approach to judicial decision making and believe that courts need to take bold action to increase their influence vis-à-vis other government bureaus (ibid.: 39). Still other innovative decisions are obliquely aimed not at government officials, but at a peer group of judges and academics. Taking a stand for social justice and pushing the boundaries of the law wins accolades among reformoriented legal elites (Yu 2009).

One of the best examples of local court innovation is the recent proliferation of specialized environmental benches. China's first environmental court opened in Guiyang in November 2007, followed by specialized environmental divisions of courts in Kunming and Wuxi. While more research on the politics behind these initiatives is needed, preliminary indications suggest that these are locally initiated projects designed to burnish reputations and ameliorate pressure to address pollution. Ultimately, the risks of modest innovation are typically low. Like other local experiments, environmental courts can quietly lapse into inactivity, judges can recant, and the tiny minority of unforgiven mutineers can find a new job. ${ }^{58}$

\section{CONCLUSION}

Too often, courts in single-party states are portrayed as a drilled-down exercise in political authority, a wafer of external validation for decisions made by and for political elites. Yet this shorthand understanding - correct in broad strokes and certainly easy to grasp - overlooks the process by which political goals are transmitted, prioritized, and understood. Here, leaders face choices about both how much flexibility to write into the law and how frequently to intervene in individual cases. While regimes may aspire to a single standard of justice, decisions often depend on the political signals surrounding either a type of case or a specific lawsuit. Conceptually, recognizing that illiberal courts are rarely monolithic also opens up room for further research on the sources and consequences of variation. The four profiles of judicial logic sketched here are a start, but much more remains to 
be done. If environmental cases oscillate between rough justice and imposed solutions, when (if at all) do Chinese courts tend toward legalism or legalized subservience? More broadly, how do judicial decision making and the accompanying space for legal innovation vary by region, type of case, or level of court? And how does this relate to judges' self-image? Do Chinese judges see themselves as social workers, bureaucrats, or adjudicators, or, more likely, do they switch between these roles as the situation demands?

Those less concerned with future research than with China's only-tooimmediate environmental problems, however, will want to know what this means for environmental protection. In a place where local Environmental Protection Bureaus (EPBs) frequently lack the power and resources to enforce regulations (Jahiel 1994; Ma and Ortolano 2000; Van Rooij 2006b; Tilt 2007), can a combination of rough justice and imposed solutions backstop environmental laws and stop pollution? In Brazil, another developing country with tightening environmental standards and ineffectual regulatory agencies, active public prosecutors have used litigation to enforce environmental law and make it matter (McAllister 2008). Thanks to prosecutors' efforts, Brazilian legal institutions are now known for "integrity, political independence and public responsiveness," and as good places to resolve environmental problems (ibid.: 13). But Chinese courts enjoy no such reputation. They are widely regarded as weak and risk-averse, far more likely to back development interests than to stop pollution. Courts also routinely refuse cases, sometimes without providing a legal, written reason. Even those directly affected by pollution, the only group allowed to sue under current Chinese law, are not guaranteed a court hearing. It is no wonder that most would-be plaintiffs see lawsuits, as one put it, as the "last road" (zuihou yitiao lu) when administrative options fail (PC 2007-56). Unlike activist judiciaries in other developing countries like India, it is difficult to imagine Chinese courts holding government accountable for policy implementation (Narain and Bell 2005) or expounding on sustainable development in court decisions (Preston 2006). Law, at least for the time being, distantly trails administrative targets as the primary means of abating pollution (Guttman 2008). ${ }^{59}$

Although environmental enforcement remains government-led, however, an emerging civic conversation is grappling with the idea of making courts more central. In the 2000s, academics and journalists began writing about environmental public interest litigation and the possibility of expanding standing so that a wider range of groups and individuals can sue. By 2007, researchers at Zhongnan University of Economics and Law could claim a "consensus among scholars" that some combination of the procuratorate, environmental bureaus, NGOs, and citizens should be allowed to initiate public interest environmental litigation. ${ }^{60}$ Although legislation has not yet changed, this discussion indicates growing support for the idea that China should "give law greater clout in [the] battle against pollution" (Jiang 2006). In addition, occasional flurries of legal creativity, as seen in the cases discussed here, may slowly validate new types of environmental rhetoric and 
claims. In this way, courts nudge forward social change in a "local, personal and incremental way" (Roach Anleu and Mack 2007: 183).

Advocacy of public interest environmental litigation and tolerance for limited judicial innovation both reflect guarded government interest in bottom-up enforcement. Letting citizens serve as watchdogs is an appealing, low-cost way to train finite resources on the worst problems. Allowing citizen voices to influence government policy, leaders seem to be betting, is safe as long as complaints do not challenge the one-party orthodoxy (Gilboy and Read 2008). In this way of thinking, responsive authoritarianism is more resilient than the police-state alternative. This shift is significant. Experiments in citizen participation, visible in complaint hotlines, public hearings, and the expansion of government legal aid, mark a noteworthy broadening of the old state-led enforcement strategy. Still, the direction of change is not inevitable. Tolerence for innovation can be abruptly rescinded and pioneers punished for what, only yesterday, was worthy of emulation.

RACHEL E. STERN is a Junior Fellow at the Harvard University Society of Fellows. Earlier work on activism in Hong Kong and China has appeared in the journals Asian Survey, Current Anthropology and Mobilization. Recent publications include "Studying Contention in Contemporary China" (with Kevin J. O’Brien) in the edited volume Popular Protest in China (2008).

\section{NOTES}

1. For a typical example, see former Politburo Standing Committee member Luo Gan's 2006 speech: "There is no question about where legal departments should stand. The correct political stand is where the party stands" (quoted in Kahn 2007).

2. The image of the commanding heights of leadership and the trenches of political decision making comes from Migdal and his anthropology of the state (2001). Environmental inspectors, of course, interact daily with polluters and are also on the frontlines of environmental protection in a different way.

3. This article is part of a larger project on environmental litigation in China and draws on fieldwork conducted between November 2006 and January 2008. This sample of decisions comes from the database Beida Fayi (http://www.lawyee.net). In December 2007, my research assistant downloaded all cases from 2000-2007 containing the search terms "environment" (huanjing) or "pollution" (wuran). I discarded three decisions because they lacked basic information about the facts of the case, which left me with forty-two decisions. An independent company since 2003, Beida Fayi is one of several national legal databases aiming to become China's version of LexusNexis or Westlaw. Many of the cases on Beida Fayi are publicly available - either published on the Internet or in case compendiums compiled by courts and publishers - although the database also obtains some decisions through "cooperative relationships" (hezuo guanxi) with individual courts. Courts sometimes publish decisions online or through a court publishing house because they have reference value (cankao de zuoyong) as correct applications of the law in typical (dianxing) cases. 
4. On how legal decisions are getting longer and better, also see Peerenboom (2002).

5. Some courts are much busier. A Southern Weekend profile of one of China's busiest courts reported a caseload of 7,540 cases split among thirteen judges (Zhao 2008). Under these circumstances, one judge explained, if a decision "explains the case clearly, you can write it succinctly and that's fine" (Zhao 2008). American judges face similar pressure to get decisions out fast. Patricia Wald, then a judge for the District of Columbia Court of Appeals wrote in 1992 that "thinking great thoughts is . . out . . final opinions will usually be committee products with all the obstacles to virtuoso performance that entails" (178).

6. Constitutional courts have attracted an especially great deal of attention (e.g., Klug 2000; Jacobsohn 2003; Ginsburg 2003; Hirschl 2008).

7. For in-depth examinations of groundbreaking Chinese cases, see Shen (2003), Hand (2006), and Kellogg (2007).

8. For exceptions, see Ai (2008) and He (2009).

9. Talking about "political elites" rather than "the party" leaves room for the very real possibility of intraparty disagreement. The CCP is not a monolithic united front but rather a collection of bureaucracies, factions, and individuals.

10. Minor cases are heard by one judge.

11. While I have not seen official numbers on the percent of judges that are party members, small-n surveys by Chinese researchers suggest that at least $80 \%$ of judges belong to the CCP. In a 1997 article, American law professor Jerome Cohen also estimates based on personal interviews that more than $90 \%$ of judges are CCP members (797).

12. Otto Ulc makes a similar observation about courts in 1950s Czechoslovakia: "In about ninety percent of the court agenda, there was not the slightest sign of interference in our decision-making . . . But the sorry experience with the remaining ten percent and the awareness that someone might at any time inflict his 'suggestion' upon us, conditioned all our adjudication" (1972: 61).

13. Many thanks to Robert A. Kagan for his help developing this typology.

14. Releasing legal decisions to national databases almost certainly requires the approval of court leaders unwilling to harm the court's reputation by publishing decisions that they know to be wrong.

15. As the Shanxi high court wrote in 2000, "pollution within government standards does not give rise to civil responsibility" (Qingjianren Village Committee v. Shanxi Luchang, Civil Division No. 6). See also Zhang Wenjian v. Guo Guoqiang, Beijing Second Intermediate Court, No. 9040 (2004). All decisions on file with the author.

16. Again, this is striking because I would expect this sample to reflect national best practices. For examples of decisions that $d o$ reference the 2002 SPC explanation, see Zhang Hui v. Liaohe Youtian Liaohai Jituan Youxian Gongsi, Liaoning Liaohe Youtian Intermediate Court, No. 2 (2003); Yuan Wei yuan Shipin Gongsi v. Lu Kaiwen, Anhui Bangbu City Intermediate Court, No. 285 (2005).

17. Ye Hanjia et al. v. Dongwanshi Ruidefeng Huagong Youxian Gongsi, Guangdong Dongwan Intermediate Court, No. 219 (2001).

18. Many interviewees talked about the greening of the state, especially PCs 2006-7, 2007-11, 2007-53, 2007-59, 2007-62, 2007-68, 2007-75, 2007-86, 2007-103, 2007108, 2007-116, 2007-118.

19. The court president (yuan zhang) is elected and dismissed by the relevant people's congress. The vice president, division heads (ting zhang), and assistant division heads (fu ting zhang) are appointed and dismissed by the standing committee of the people's congress (Zhu 2007). The party committee of the local government must approve all names before they are submitted to the people's congress for approval (Zhu 2007: 179). For more on the importance of court officials, see Peerenboom (2002: 281, 284-85), Liu (2006: 93), and Liebman (2007: 627). 
20. 62 Families From Damengwu Village v. Lianhe Xian Yuantong Liuhuangchang, Yunnan Lianhe Basic Court, Civil Division, No. 51 (2005).

21. For more on adjudication committees, see Upham (2005). While no official numbers are available, the committee reportedly hears less than 1 percent of all cases.

22. Guangzhou Basic Level Court, quoted in Guangzhou Poya Dengshi Zhizao Youxian Gongsi v. Xie Zantian, Guangdong Guangzhou Intermediate Court, Civil Division No. 1770 (2005).

23. The supervisory division of individual courts and the local procuratorate determine "wrong cases" through an investigation of cases that were changed on appeal (gai shen), re-heard (zai shen), or that generate complaints.

24. Looking at decisions is one way to infer judicial goals and motives from judicial behavior. Another worthwhile tack would be to ask judges directly how they make decisions.

25. Qinghianren Village Committee v. Shanxi Luchang (2000). As one would expect, there was a difference between the amount of compensation requested in mass cases (cases with more than five plaintiffs) and nonmass cases. The average request for compensation in mass cases was RMB 2.7 million (US\$396,164), and the average request for compensation in nonmass cases was RMB776,518 (US\$114,193). I have full data on the amount of compensation requested and the amount of compensation received for thirty-nine of the forty-two cases, including eight mass cases and thirty-one nonmass cases. I coded one case where the village committee served as a plaintiff at a mass case because compensation claims were made on behalf of the entire village (e.g., more than five people). Under these circumstances, the political logic of the case should be more similar to a mass case than an individual lawsuit. Conversions to U.S. dollars throughout this article are based on an exchange rate of RMB6.8 to US\$1.

26. Yang Hanqiu v. Disan Hangwu Gongchengju Diliu Gongcheng Gongsi, Fuijian Xiamen Intermediate Court (2002).

27. Guangzhou Poya Dengshi Zhizao Youxian Gongsi v. Xie Zantian (2005).

28. Chen Renxia v. Yin Hongxia, Anhui Chuzhou Intermediate Court, Civil Division No. 120 (2004).

29. Lu Baoyin et al. v. Hebei Bada Jituan Mancheng Shuini Youxian Gongsi, Hebei Mancheng Basic Court, No. 453 (2000).

30. Ningboshi Beilunqu Baifengshang Yangdianhua Yichang et al. v. Wang Shouxiang, Zhejiang Ningbo Intermediate Court, Civil Division, No. 440 (2002).

31. Zhang Pengguo and Li Yuping v. Shengli Youtian Gongyi Xinjishu Shiyou Kaifa Youxian Zeren Gongsi, Shandong Dongyang Intermediate Court, Civil Division No. 27 (2004).

32. Without more information about these cases, it is hard to know how to interpret judges' instance on an official receipt. This could be a way to show favoritism to defendants or an attempt to ensure plaintiffs are not inflating claims. For example, see Zhang Pengguo and Li Yuping v. Shengli Youtian Gongyi Xinjishu Shiyou Kaifa Youxian Zeren Gongsi (2004) and Yuan Wei Shipin Gongsi v. Lu Kaiwen (2005).

33. Courts often have trouble enforcing their decisions and I am not making any claims about how much money plaintiffs actually received. Rather, this is the amount ordered by the court. This 29 percent figure includes cases in which plaintiffs lost and were awarded no damages.

34. Ping Zao v. Zhongnan Shiyouju, Guangdong Foshan Intermediate Court, Civil Division No. 3 (2005).

35. Guangzhou Poya Dengshi Zhizao Youxian Gongsi v. Xie Zantian (2005). 
36. Lu Yaodong v. Shanghai Yongda Zhongbao Qiche Xiaoshou Fuwu Youxian Gongsi, Shanghai Pudong Basic Court (2004).

37. Yin Bingquan et al. v. Beijing Tieluju, Beijing Railway Court, No. 23 (2001).

38. For more on how basic-level courts are rooted in local communities, see Upham (2005).

39. Zhumadianshi Suyahu Shuiku Guanliju v. Zhumadianshi Yicheng Hongyuan Waleng Banzhichang, Henan Runan Basic Court, Civil Division No. 30 (2003).

40. Ye Hanjia v. Ruidefeng Gongsi (2001).

41. 62 Families From Damengwu Village v. Lianhe Xian Yuantong Liuhuangchang (2005).

42. Lu Yaodong v. Shanghai Yongda Zhongbao Qiche Xiaoshou Fuwu Youxian Gongsi (2004).

43. 62 Families From Damengwu Village v. Lianhe Xian Yuantong Liuhuangchang (2005).

44. Damu Linzhabu et al. v. Dongwu Zhumu Qinqi Dianhua Jiangbanchang et al., Inner Mongolia High Court, Civil Division No. 36 (2004).

45. Lu Yaodong v. Shanghai Yongda Zhongbao Qiche Xiaoshou Fuwu Youxian Gongsi (2004).

46. Wan Hongxiang et al. v. Lianshui xian Guanglin, Jiangsu Lianshui Basic Court, No. 1117 (2000); see also Lu Yaodong v. Shanghai Yongda Zhongbao Qiche Xiaoshou Fuwu Youxian Gongsi (2004).

47. Wan Hongxiang et al. v. Lianshui xian Guanglin (2000); Yang Hanqiu v. Disan Hangwu Gongchengju Diliu Gongcheng Gongsi, Fuijian High Court (2002); Shi Meizhen v. Nanjing Aihua Zhuangshi Youxian Zeqian Gongsi, Nanjing Gulou Basic Court, No. 208 (2002).

48. In the Baotou case, the court ordered RMB2.8 million in compensation (US\$411,764). For more on the case, see Fürst (2008: especially 47-50).

49. Xiong Wansheng v. Beijingshi Zonghe Touzi Gongsi et al., Beijing Second Intermediate Court, Civil Division No. 5696 (2000). See also Gong Changjiu et al. v. Shen Xiang, Chongqing Basic Court, Civil Division, No. 1045 (2006).

50. Qingjianren Village Committee v. Shanxi Luchang (2000).

51. Chen Renxia v. Yin Hongxia, Anhui Chuzhou Intermediate Court (2004).

52. Yang Hanqiu v. Disan Hangwu Gongchengju Diliu Gongcheng Gongsi (2002).

53. For more on the importance of rights-based claims, see O'Brien and Li (2006).

54. Competition between legal databases over the next several years should put more cases online and, by extension, make it much easier for judges to research cases.

55. Liu Fangyu v. Qinzhou Guoxing Youqi Youxian Gongsi et al., Guangxi High Court No. 21 (2002).

56. Zhejiang Jianchayuan v. Jiaxingshi Buyun Ranhuachang, Zhejiang High Court No. 17 (2000).

57. For more on the importance of decentralized experimentation, see Heilmann (2008) as well as O'Brien (2009: 134).

58. On how local experiments quietly fade away, see Heilmann (2008). On how rebellious judges can find a new job, see Yu (2009).

59. Strengthening environmental criteria on cadre evaluations would likely have more effect than even a landmark lawsuit. See van Rooij (2006b) on the importance of evaluation systems.

60. Across the board, government officials advocate a cautious approach. Bie Tao, well-known as a champion of public interest litigation within the Ministry of the Environment, believes that standing should be limited to government-approved NGOs (2007). Many academics agree that slowly expanding standing is a good idea (e.g., Zhang 2003a; Xing 2005) and citizen lawsuits, at least for the more wary, should be a "last resort" (Zhang 2004). 


\section{REFERENCES}

Ai, Jiahui (2008) "Managing Court Personnel Amid Social Transition" ["Shehui Bianqian Zhong de Fayuan Renshi Guanli"]. PhD diss., Beijing Univ. Law School.

Amsterdam, Anthony G., and Jerome Bruner (2000) Minding the Law. Cambridge, MA: Harvard Univ. Press.

Baum, Lawrence (2006) Judges and Their Audiences. Princeton, NJ: Princeton Univ. Press.

Bie, Tao, ed. (2007) Public Interest Environmental Litigation [Huanjing Gongyi Susong]. Beijing: Law Press.

Chaskalson, Arthur (2003) "From Wickedness to Equality: The Moral Transformation of South African Law," International Journal of Constitutional Law 1 (3): 590-609.

Coates, Austin ([1968] 1987) Myself a Mandarin: Memoirs of a Special Magistrate. Hong Kong: Oxford Univ. Press.

Cohen, Jerome A. (1997) "Reforming China's Civil Procedure: Judging the Courts," American Journal of Comparative Law 45 (4): 793-804.

Epstein, Lee, Jack Knight, and Olga Shvetsova (2001) "The Role of Constitutional Courts in the Establishment and Maintenance of Democratic Systems of Government," Law \& Society Review 35: 117-64.

Feynman, Richard P. ([1988] 2007) What Do You Care What Other People Think? Further Adventures of a Curious Character. New York: Penguin Books.

Fürst, Kathinka (2008) "Access to Justice in Environmental Disputes: Opportunities and Obstacles of Chinese Pollution Victims.” MA diss., Univ. of Oslo.

Gilboy, George J., and Benjamin L. Read (2008) "Political and Social Reform in China: Alive and Walking," Washington Quarterly 31 (3): 143-64.

Ginsburg, Tom (2003) Judicial Review in New Democracies: Constitutional Courts in Asian Cases. New York: Cambridge Univ. Press.

Ginsburg, Tom, and Tamir Moustafa, eds. (2008) Rule by Law: The Politics of Courts in Authoritarian Regimes. New York: Cambridge Univ. Press.

$\mathrm{Gu}$, Peidong (2008) "On the Settlement Mechanism of Irregular Disputes in China," Frontiers of Law in China 3 (2): 256-93.

Guttman, Dan (2008) "Different Operating Systems," Environmental Forum November/December: 27.

Hand, Keith J. (2006) "Using the Law for a Righteous Purpose: Sun Zhigang and Evolving Forms of Citizen Action in the People's Republic of China," Columbia Journal of Transnational Law 43 (3): 114-93.

He, Weifang (1999) "Realizing Social Justice Through the Judicial System: A Perspective on Chinese Judges' Situation [Tongguo Sifa Shixian Shehui Zhengyi: Dui Zhongguo Faguan Xianzhuang de Yige Toushi]." In Toward an Age of Rights, edited by X. Yong. Beijing: Zhongguo Zhengfa Univ. Press.

$\mathrm{He}$, Xin (2007) "The Recent Decline in Economic Caseloads in Chinese Courts: Exploration of a Surprising Puzzle," China Quarterly 190: 352-74.

$\mathrm{He}$, Xin (2009) "Routinization of Divorce Law Practice in China: Institutional Constraints' Influence on Judicial Behavior," International Journal of Law, Policy and the Family 23: 83-109.

Heilmann, Sebastian (2008) "From Local Experiments to National Policy: The Origins of China's Distinctive Policy Process," China Journal 59: 1-30.

Hilbink, Lisa (2007) Judges Beyond Politics in Democracy and Dictatorship. New York: Cambridge Univ. Press.

Hirschl, Ran (2008) "The Judicialization of Mega-Politics and the Rise of Political Courts," Annual Review of Political Science 11: 93-118. 
Jacobsohn, Gary (2003) The Wheel of Law: India's Secularism in Comparative Constitutional Perspective. Princeton, NJ: Princeton Univ. Press.

Jahiel, Abigail R. (1994) "Policy Implementation Through Organizational Learning: The Case of Water Pollution Control in China's Reforming Socialist System." PhD Diss., Univ. of Michigan.

Jiang, Ping (2006) "Give Law Greater Clout in Battle Against Pollution," China Daily (31 July). Available at http://www.chinadaily.com.cn/opinion/2006-07/31/ content_653096.htm.

Kahn, Joseph (2007) "Chinese Official Warns Against Independence of Courts," New York Times (3 February). Available at http://www.nytimes.com/2007/02/03/world/ asia/03china.html.

Kapiszewski, Diana, and Mathew M. Taylor (2008) "Doing Courts Justice? Studying Judicial Politics in Latin America," Perspectives on Politics 6 (4): 741-67.

Kellogg, Thomas E. (2007) "Courageous Explorers'? Education Litigation and Judicial Innovation in China," Harvard Human Rights Journal 20: 141-84.

Klug, Heinz (2000) Constituting Democracy: Law, Globalism and South Africa's Political Reconstruction. New York: Cambridge Univ. Press.

Lan, Rongjie (2008) "Empirical Research on the Localization of Litigation Rules [Susong Guize Difanghua Shizheng Yanjiu]," Law and Social Development [Zhengzhi yu Shehui Fazhan] 14 (2): 13-22.

Liebman, Benjamin L. (2007) "China's Courts: Restricted Reform," China Quarterly 191: $620-38$.

Liebman, Benjamin L., and Timothy Wu (2007) "China's Network Justice." Columbia Public Law Research Paper No. 07-143. Available at http://papers.ssrn.com/ sol3/papers.cfm?abstract_id=956310.

Lora-Wainwright, Anna (2009) "Of Farming Chemicals and Cancer Deaths: The Politics of Health in Rural China," Social Anthropology 17 (1): 56-73.

Liu, Sida (2006) "Beyond Global Convergence: Conflicts of Legitimacy in a Chinese Lower Court," Law \& Social Inquiry 31 (1): 75-106.

Ma, Xiaoying, and Leonard Ortolano (2000) Environmental Regulation in China. Lanham, MD: Rowman \& Littlefield Publishing Group.

Mackey, Robert (2007) "Expert Roundtable: China-Choking on Growth," New York Times 29 August. Available at http://china.blogs.nytimes.com/2007/08/29/ thursdays-expert-zhang-jingjing.

Markovits, Inga (1996) "Children of a Lesser God: GDR Lawyers in Post-Socialist Germany," Michigan Law Review 94: 2270-308.

Merryman, John (1985) The Civil Law Tradition: An Introduction to the Legal Systems of Western Europe and Latin America. Stanford, CA: Stanford Univ. Press.

McAllister, Lesley K. (2008) Making Law Matter: Environmental Protection and Legal Institutions in Brazil. Stanford, CA: Stanford Univ. Press.

Migdal, Joel S. (2001) State in Society. New York: Cambridge Univ. Press.

Moustafa, Tamir (2007) The Struggle for Constitutional Power: Law, Politics and Economic Development in Egypt. New York: Cambridge Univ. Press.

Nader, Laura (1990) Harmony Ideology: Justice and Control in a Zapotec Mountain Village. Stanford, CA: Stanford Univ. Press.

Narain, Urvashi, and Ruth Greenspan Bell (2005) Who Changed Delhi's Air? The Roles of the Court and the Executive in Environmental Policymaking. Washington DC: Resources for the Future. Available at http://www.rff.org/Documents/RFFDP-05-48.pdf.

Nonet, Philippe, and Philip Selznick ([1971] 2001) Toward Responsive Law. New York: Transaction Publishers.

O’Brien, Kevin J. (2009) "Local People's Congresses and Governing China," China Journal 61: 131-41. 
O'Brien, Kevin J., and Lianjiang Li (2006) Rightful Resistance. New York: Cambridge Univ. Press.

Pan, Yue (2006) "An Environmentally Friendly Society Under the Goal of Harmonious Society [Hexie Shehui Mubiao Xia De Huanjing Youhaoxing Shehui].” Twenty First Century Economic Herald: 34.

Peerenboom, Randall (2002) China's Long March Toward Rule of Law. New York: Cambridge Univ. Press.

Plumer, Bradford (2008) "Cultural Devolution: Solving China's Environmental Catastrophe," New Republic 9 July. Available at http://www.tnr.com/toc/ story.html?id=9ef5103b-15cf-4bd6-b7a1-34940b9edeca.

Popova, Maria (2006) "Watchdogs or Attack Dogs? The Role of Russian Courts and the Central Election Commission in the Resolution of Electoral Disputes," EuropeAsia Studies 58 (3): 391-414.

Posner, Richard A. (1993) "What Do Judges and Justices Maximize?" Supreme Court Economic Review 3: 1-41.

Preston, Brian J. (2006) "The Role of the Judiciary in Promoting Sustainable Development: The Experience of Asia and the Pacific," Asian Pacific Journal of Environmental Law 9 (2\&3): 109-211.

Roach Anleu, Sharyn, and Kathy Mack (2007) "Magistrates, Magistrate Courts and Social Change," Law \& Policy 29 (2): 183-209.

Shapiro, Martin (1981) Courts: A Comparative and Political Analysis. Chicago: Univ. of Chicago Press.

Shen, Kui (2003) "Is It The Beginning of the Era of the Rule of the Constitution? Reinterpreting China's 'First Constitutional Case," Pacific Rim Law and Policy Journal 12: 199-232.

Silverstein, Gordon (2003) "Globalization and the Rule of Law: 'A Machine That Runs of Itself?" " International Journal of Constitutional Law 1 (3): 427-45.

Supreme People's Court Gazette (2005) "Liu Yaodong Sues Yongda [Liu Yaodong Su Yongda Gongsi]," Supreme People’s Court Gazette [Zhongguo Renmin Gonghego Zui Gao Renmin Fayuan Gongbao] 5: 40-42.

Tilly, Charles (2008) Credit and Blame. Princeton, NJ: Princeton Univ. Press.

Tilt, Bryan (2007) "The Political Ecology of Pollution Enforcement in China: A Case From Sichuan's Rural Industrial Sector," The China Quarterly 192: 91532.

Toharia, Jose J. (1975) Judicial Independence in an Authoritarian Regime: The Case of Contemporary Spain," Law \& Society Review 9 (3): 475-96.

Ulc, Otto (1972) The Judge in a Communist State: A View From Within. Athens: Ohio Univ. Press.

Upham, Frank K. (2005) "Who Will Find the Defendant If He Stays with His Sheep? Justice in Rural China," Yale Law Journal 114: 1675-718.

Van Rooij, Benjamin (2006a) "Implementation of Chinese Environmental Law: Regular Enforcement and Political Campaigns," Development and Change 37 (1): $57-74$.

Van Rooij, Benjamin (2006b) Regulating Land and Pollution in China: Lawmaking, Compliance and Enforcement; Theory and Cases. Leiden, Netherlands: Leiden Univ. Press.

Wang, Canfa, ed. (2005) Cases in Environmental and Natural Resource Protection Law [Huangjing yu Ziyuan Baohufa Anli]. Beijing: Renmin Univ. Press.

Wald, Patricia (1992) "Some Real-Life Observations About Judging," Indiana Law Review 26 (1): 173-86.

Xing, Hong (2005) "Comparative Research on Public Interest Litigation and Its Lessons for Chinese Environmental Law [Gongyi Susong Bijiao Yanjiu Jiqi Woguo Huanjing Lifa de Qishi]," Xueshu Jiaoliu 4: 50-53. 
Yu, Xiaohong (2009) "Rise of Local Courts in China: Judicial Hierarchy, Institututional Adaptation and Regime Resilience." Conference paper presented at China's Changing Courts, Columbia Univ. Law School.

Zhang, Shijun (2004) "A Discussion of Realizing Public Environmental Litigation Rights [Lun Gongzhong Huanjing Suquan de Shixian]," Journal of Wuhan University 22 (11): 36-40.

Zhang, Qianfan (2003) "The People's Court in Transition: The Prospects of the Chinese Judicial Reform," Journal of Contemporary China 12 (34): 69-101.

Zhang, Xuehua (2008) "Enforcing Environmental Regulations in Hubei Province, China: Agencies, Courts, Citizens." PhD diss., Stanford Univ.

Zhang, Zitai (2003a) "An Analysis of Difficulties and Strategies in Chinese Environmental Administrative Lawsuits [Zhongguo Huanjing Xingzheng Susong Zhi Kunnan yu Duice Fenxi]," Legal Commentary [Faxue Pinglun] 5: 138-43.

Zhao, Lei (2008) "China's Busiest Court [Zhongguo Zui Mang de Fayuan]," Southern Weekend [Nanfang Zhoumou] 4 December. Available at http://www.infzm.com/ content $/ 20845$.

Zhou, Litai (2005) "Who Protects Lawyers' Rights? [Shei Lai Weihu Lushi de Quanyi?]." In Concerning Justice [Yu Zhengyi You Guan], edited by G. Zhao. Beijing: Huacheng Publishing Company.

Zhu, Jingwen (2007) Report on China Law Development: Database and Indicators [Zhongguo Falu Fazhan Baogao]. Beijing: Renmin Univ. Press.

Zhuang, Pinghui (2006) "Yellow River Polluters Hit with 2.3 m Yuan Payout Bill," South China Morning Post. 5 January.

\section{CASES CITED}

Anhui Bangbu City Intermediate Court (2005) Yuan Wei yuan Shipin Gongsi v. Lu Kaiwen, No. 285.

Anhui Chuzhou Intermediate Court (2004), Chen Renxia v. Yin Hongxia, Civil Division No. 120.

Beijing Second Intermediate Court (2000), Xiong Wansheng v. Beijingshi Zonghe Touzi Gongsi et al., Civil Division No. 5696.

Beijing Second Intermediate Court (2004), Zhang Wenjian v. Guo Guoqiang, No. 9040 (2004).

Beijing Railway Court (2001), Yin Bingquan et al. v. Beijing Tieluju, No. 23.

Chongqing Basic Court (2006), Gong Changjiu et al. v. Shen Xiang, Civil Division, No. 1045.

Fuijian Xiamen Intermediate Court (2002), Yang Hanqiu v. Disan Hangwu Gongchengju Diliu Gongcheng Gongsi.

Guangdong Dongwan Intermediate Court (2001), Ye Hanjia et al. v. Dongwanshi Ruidefeng Huagong Youxian Gongsi, No. 219.

Guangdong Foshan Intemediate Court (2005), Ping Zao v. Zhongnan Shiyouju, Civil Division No. 3.

Guangdong Guangzhou Intermediate Court (2005), Guangzhou Poya Dengshi Zhizao Youxian Gongsi v. Xie Zantian, Civil Division No. 1770.

Guangxi High Court (2002), Liu Fangyu v. Qinzhou Guoxing Youqi Youxian Gongsi et al., No. 21.

Hebei Mancheng Basic Court (2000), Lu Baoyin et al. v. Hebei Bada Jituan Mancheng Shuini Youxian Gongsi, No. 453.

Henan Runan Basic Court (2003), Zhumadianshi Suyahu Shuiku Guanliju v. Zhumadianshi Yicheng Hongyuan Waleng Banzhichang, Civil Division No. 30.

Inner Mongolia High Court (2004), Damu Linzhabu et al. v. Dongwu Zhumu Qinqi Dianhua Jiangbanchang et al. Civil Division No. 36. 
Jiangsu Lianshui Basic Court (2000) Wan Hongxiang et al. v. Lianshui xian Guanglin Bingbangchang, No. 1117.

Liaoning Liaohe Youtian Intermediate Court (2003) Zhang Hui v. Liaohe Youtian Liaohai Jituan Youxian Gongsi et al., No. 2.

Nanjing Gulou Basic Court (2002) Shi Meizhen v. Nanjing Aihua Zhuangshi Youxian Zeqian Gongsi, No. 208.

Shandong Dongyang Intermediate Court (2004) Zhang Pengguo and Li Yuping v. Shengli Youtian Gongyi Xinjishu Shiyou Kaifa Youxian Zeren Gongsi, Civil Division No. 27.

Shanghai Pudong Basic Court (2004) Lu Yaodong v. Shanghai Yongda Zhongbao Qiche Xiaoshou Fuwu Youxian Gongsi.

Shanxi High Court (2000), Qingjianren Village Committee v. Shanxi Luchang, Civil Division No. 6.

Yunnan Lianhe Basic Court (2005) 62 Families From Damengwu Village v. Lianhe Xian Yuantong Liuhuangchang, Civil Division No. 51.

Zhejiang High Court (2000) Zhejiang Jianchayuan v. Jiaxingshi Buyun Ranhuachang, No. 17.

Zhejiang Ningbo Intermediate Court (2002) Ningboshi Beilunqu Baifengshang Yangdianhua Yichang et al. v. Wang Shouxiang, Civil Division, No. 440.

\section{PERSONAL COMMUNICATIONS CITED}

2006-6 Former Chinese judge (Zhejiang), New York City, 26 October 2006.

2007-7 Chinese plaintiff in an environmental lawsuit, Beijing, 24 January 2007.

2007-11 Environmental reporter, Beijing, 1 February 2007.

2007-23 Chinese lawyer, Beijing, 14 March 2007.

2007-27 Chinese lawyer, Jiangsu, 20 March 2007.

2007-38 Chinese environmental journalist, Beijing, 19 April 2007.

2007-51 Chinese lawyer, Beijing, 12 May 2007.

2007-53 Chinese lawyer, Shanghai, 24 May 2007.

2007-55 Chinese judge, Shanghai, 25 May 2007.

2007-56 Chinese plaintiff, Zhejiang, 28 May 2007.

2007-57 Chinese lawyer, Zhejiang, 29 May 2007.

2007-59 Chinese environmental NGO representatives, Beijing, 5 July 2007.

2007-62 Chinese environmental journalist, Beijing, 11 July 2007.

2007-68 Environmental Protection Bureau official, Jilin, 16 August 2007.

2007-74 Chinese judge, Hebei, 28 August 2007.

2007-75 Chinese environmental journalist, Beijing, 30 August 2007.

2007-84 Chinese judge, Beijing, 18 September 2007.

2007-85 Chinese judge, Beijing, 20 September 2007.

2007-86 Environmental Protection Bureau official, Shanghai, 24 September 2007.

2007-97 Chinese lawyer, Beijing, 25 October 2007.

2007-99 Chinese lawyer (Inner Mongolia), Beijing, 29 October 2007.

2007-103 Chinese lawyer, Jiangsu, 7 November 2007.

2007-108 Chinese lawyer, Guangxi, 18 November 2007.

2007-116 Chinese academic, Beijing, 18 December 2007.

2007-118 Chinese lawyer, Shanghai, 27 December 2007.

2009-5 Chinese lawyer, Beijing, 20 January 2009. 